\title{
A REGCM4.7 REGIONÁLIS ÉGHAJLATI MODELL ÉRZÉKENYSÉGE A FÖLDFELSZÍNI ÉS A PLANETÁRIS HATÁRRÉTEG SÉMÁKRA A KÁRPÁT-MEDENCE TÉRSÉGÉBEN
}

\author{
Kalmár Tímea (D), Pieczka Ildikó iD, Pongrácz Rita \\ ELTE Meteorológiai Tanszék, 1117 Budapest, Pázmány Péter sétány 1/A \\ e-mail:kalmartimea@caesar.elte.hu,pieczka@nimbus.elte.hu,prita@nimbus.elte.hu
}

\section{Bevezetés}

Az éghajlati modellek kulcsszerepet játszanak az éghajlati rendszer müködésének minél pontosabb megértésében, emiatt egyértelmüen szükséges a folyamatos fejlesztésük és tesztelésük. A modellek fontos részét képezik a rácshálózatnál finomabb felbontású folyamatok - mint például a földfelszínre érkező sugárzás mennyiségének, a planetáris határréteg alakulásának vagy a felhö- és csapadékképző folyamatok - leírását szolgáló parametrizációs sémák. Az éghajlati modellek fejlődése következtében egyre nagyobb a választási lehetőség a különböző sémák kiválasztása során, amely széleskörü tesztelési lehetőséget nyújt a felhasználók számára. Ugyanakkor fontos megjegyezni, hogy nincs egyetlen univerzálisan jó kombináció az egész Földre vonatkozólag, s a különféle felhasználói körök irányából érezhetően megnőtt az igény a lehető legjobb kombináció megtalálására adott területekre.

A klímamodellezéshez köthető nemzetközi kutatásokba az ELTE Meteorológiai Tanszéke is bekapcsolódott - ennek keretében több mint tíz éve folynak kutatások a RegCM ${ }^{1}$ regionális éghajlati modell adaptálásával és érzékenységvizsgálatával kapcsolatban (Torma et al., 2011; Pieczka et al., 2017; Kalmár et al., 2020). Jelen vizsgálat során a modellfutások a RegCM legújabb verziójával (RegCM4.7) 10 km-es horizontális felbontás mellett készültek a Kárpátmedencére a 2010-es évre, amely az eddigi legcsapadékosabb év volt Magyarországon a megbízható rendszeres mérések kezdete óta. A tesztelés során föleg a felszíni folyamatokra fókuszálunk, nevezetesen a felszín-légkör kölcsönhatást leíró felszíni almodellekre, illetve a planetáris határréteget leíró sémákra, mivel ezek a folyamatok jelentős szerepet játszanak az időjárási és éghajlati viszonyok kialakításában (pl. Knist et al., 2017).

\section{Modellbeállítások és futtatások}

A vizsgálat során az $\mathrm{ICTP}^{2}$ által fejlesztett RegCM regionális klímamodellt (Elguindi et al., 2014) alkalmaztuk. A RegCM4.7-tel elvégzett modellfuttatások 10 km-es horizontális felbontás mellett a Kárpát-medencét magában foglaló területre $(120 \times 216$ rácspontra, 23 vertikális szinten) történtek. A teljes integrálási idő 2009.12.01-2010.12.31, melyből az első évet felpörgési időként tekintettük, s így az értékelésből kihagytuk. A kezdeti- és peremfeltételeket az ERA-Interim (Dee et al., 2011) reanalízis adatbázis $\left(0,75^{\circ}\right.$-os horizontális felbontás mellett) szolgáltatta. A vizsgálat során négy különböző beállítással futtattuk a modellt: két felszíni almodell (BATS ${ }^{3}$ (Dickinson et al., 1993) és CLM4.5 (Oleson et al., 2010)) és két planetáris határréteg (PHR) séma (Holtslag (Holtslag et al., 1990) és $\mathrm{UW}^{5}$ (Bretherton et al., 2004)) kombinációjával végeztünk futtatásokat (1. táblázat).

\footnotetext{
${ }^{1}$ Regional Climate Model - regionális éghajlati modell

${ }^{2}$ International Centre for Theoretical Physics

${ }^{3}$ Biosphere-Atmosphere Transfer Scheme - Bioszféra-atmoszféra transzfer modell

${ }^{4}$ Community Land Model version 4.5 - Közösségi felszíni modell 4.5-ös verziója

${ }^{5} \mathrm{UW}$ : University of Washington
} 
1. táblázat: Az elvégzett szimulációk főbb jellemzői.

\begin{tabular}{|c|c|c|c|c|}
\hline & BATS_HO & BATS_UW & CLM_HO & CLM_UW \\
\hline $\begin{array}{c}\text { Nagytérségü } \\
\text { csapadékséma }\end{array}$ & \multicolumn{3}{|c|}{ Módosított SUBEX séma (Torma et al., 2011) } \\
\hline $\begin{array}{c}\text { Konvektív } \\
\text { csapadékséma }\end{array}$ & \multicolumn{3}{|c|}{ Tiedtke (Tiedtke, 1989) } \\
\hline Felszíni modell & \multicolumn{3}{|c|}{ BATS (Dickinson et al., 1993) } & CLM4.5 (Oleson et al., 2010) \\
\hline PHR séma & $\begin{array}{c}\text { Holtslag } \\
\text { (Holtslag et al., } \\
1990)\end{array}$ & $\begin{array}{c}\text { UW (Bretherton } \\
\text { et al., 2004) }\end{array}$ & Holtslag & UW \\
\hline
\end{tabular}

A RegCM modellben a BATS és a CLM4.5 felszíni almodul található meg, melyek jelentősen eltérnek egymástól. A BATS séma a talajnedvesség és a növényzet szerepének leírását végzi egyszerübb formában, ahol az energia, a vízgőz és a felszíni momentum cseréjét a MoninObukhov hasonlósági elméletből számolja. Az almodell egy vegetációs réteget, egy felszíni talajréteget, egy hóréteget, 20 vegetáció típust és három talajnedvességi szintet tartalmaz (Dickinson et al., 1993). A CLM4.5 a BATS-nál összetettebb; jóval részletesebben írja le a felszíni folyamatokat, több talaj- és hóréteggel rendelkezik (rendre tíz, illetve öt réteggel), valamint 24 különböző növénytípussal. Mindezek mellett a felszíni energiaáramokat különkülön kiszámítja hófedte, vízzel borított, vegetációval borított és mezőgazdasági egységekre, továbbá a hófedte és hómentes gleccser területekre.

A planetáris határréteg leírására és modellezésére két séma áll rendelkezésre a RegCM-ben. A Holtslag-séma egy nem lokális paraméterezési séma (azaz az egész határréteget egyszerre keveri át), ahol a PHR magasság kiszámítása a Richardson-szám kritikus értéke alapján történik. Ezzel szemben az UW egy 1,5 rendü lokális (azaz csak a szomszédos légrétegek keveredhetnek egymással), lefelé gradiens diffúziós paraméterezés, amelyben a sebességi skála a turbulens kinetikus energián (TKE) alapul.

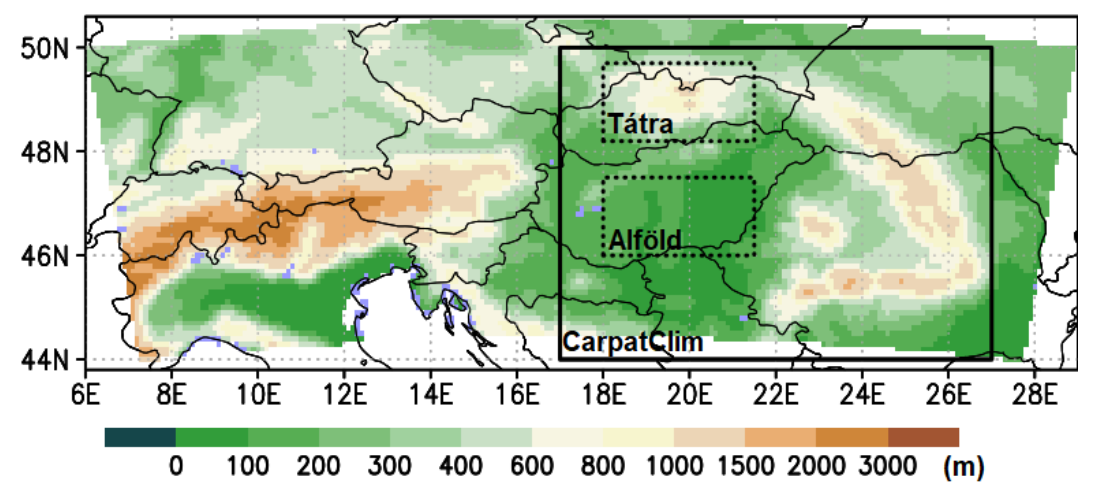

1. ábra: A RegCM teljes integrálási tartománya és a validációhoz használt CarpatClim adatbázis által lefedett terület domborzata (fekete téglalap). A vizsgálatok során kiválasztott két kisebb terület:

Tátra térsége (az északi, pontozott vonallal jelölt téglalap) és az

Alföld egy kisebb része (a déli, pontozott vonallal jelölt téglalap).

A validációhoz a CarpatClim adatbázist (Szalai et al., 2013) választottuk, mivel Magyarország területére jelenleg ez a publikusan elérhető legrészletesebb, legfinomabb $-0,1^{\circ}$-os horizontális felbontású adatbázis. A CarpatClim adatbázis idősorai közül a $2 \mathrm{~m}$-es napi középhőmérsékletet $\left({ }^{\circ} \mathrm{C}\right)$, napi csapadékösszeget $(\mathrm{mm})$, illetve a felhőborítottságot (tized) használtuk fel. A meteorológiai változók orográfiától való jelentős függése miatt az egész területre vonatkozó átlagértékek mellett két kisebb - domborzatát tekintve egymástól jelentősen 
eltérö - régiót választottunk ki, és így az egyes vizsgálatok során területi átlagokat képeztünk az Alföld déli részére és a Tátra környékére (1. ábra).

\section{Eredmények}

A modelleredmények validációs értékelése során évszakos középhőmérsékletet, valamint évszakos átlagos csapadékösszeget vetettünk össze a CarpatClim adatbázisból származtatott referencia adatokkal. Az eredmények minél jobb megértése érdekében a felhőborítottság éves menetét is felhasználtuk a CarpatClim adatbázisból. Mivel a planetáris határréteg séma jelentős szerepet játszik a felszín és a légkör közötti hö-, nedvesség- és momentumcserében, így olyan változókat is vizsgáltunk, mint például a talajnedvesség, illetve a felszíni energiaegyenleg egyes komponensei (nettó sugárzás, szenzibilis és látens hőáram, Bowen-arány).

\section{Hömérséklet és csapadék}

A 2. ábra a téli (DJF), illetve a nyári (JJA) hőmérsékleti és csapadékhibát mutatja. Jól látható, hogy mindegyik szimuláció jelentősen felülbecsüli a téli középhőmérsékletet, míg nyárra inkább az alulbecslés jellemző (kivétel a CLM_HO szimuláció esetén). A téli hőmérséklet felülbecslésének egyik lehetséges oka a hóvastagság alulbecslése, főleg a BATS-ot alkalmazó szimulációk során. Korábbi tanulmányok (pl. Varga \& Breuer, 2020) alapján is a hóborítottság vagy annak hiánya jelentősen módosíthatja a felszíni hőmérsékletet. A planetáris határréteg séma hatása is megmutatkozik a hömérsékleti hibamezökön: jól látható, hogy az UW séma mérsékli a hőmérsékleti értékeket (a nyári időszakban nagyobb mértékben), amelyet a turbulens diffúzió csökkenése okoz a Holtslag sémához képest (Güttler et al., 2014).
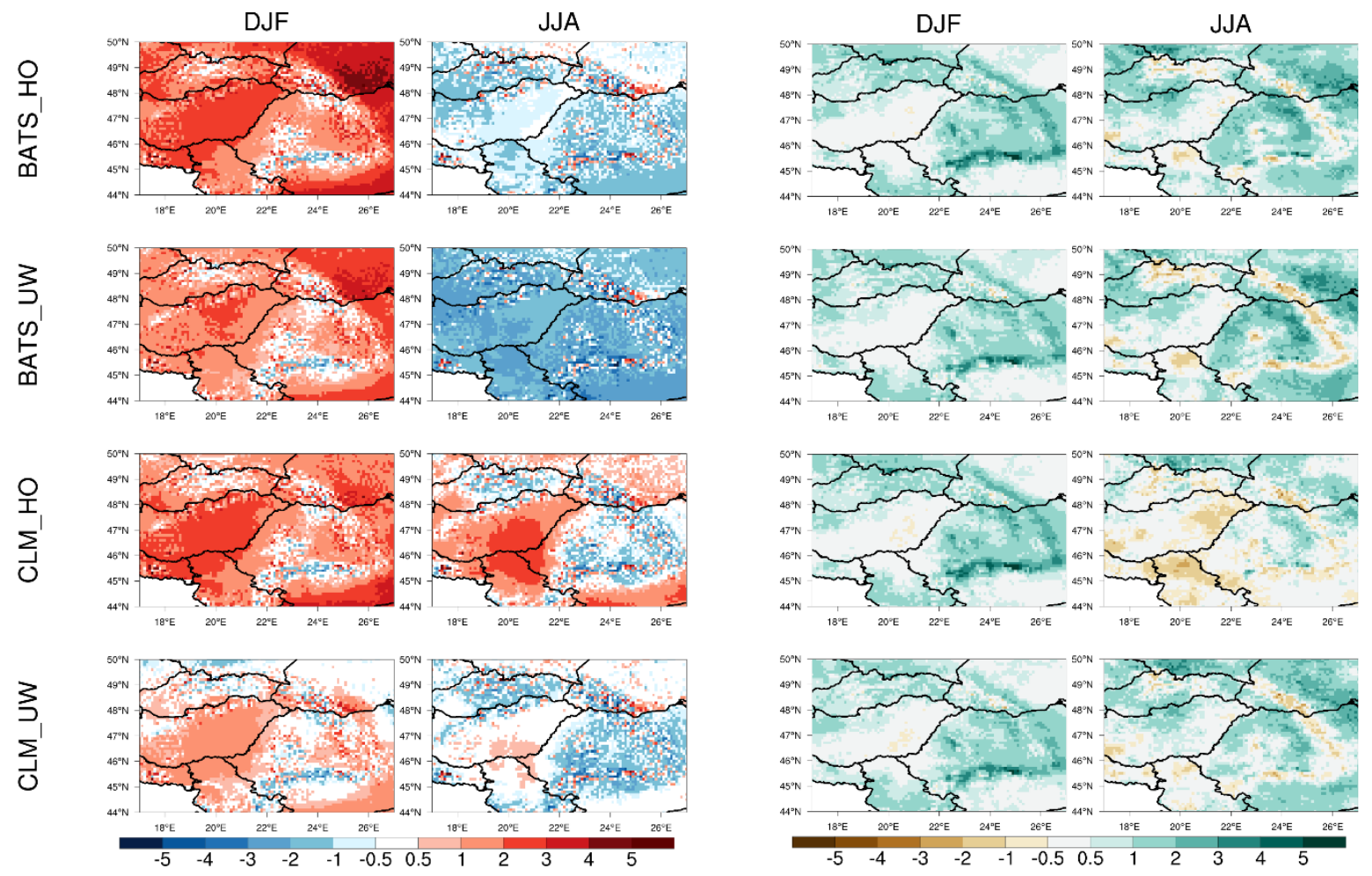

2. ábra: Az egyes modellszimulációk átlagos téli és nyári hőmérsékleti $\left({ }^{\circ} \mathrm{C}\right.$, első két oszlop) és csapadék (mm/nap, utolsó két oszlop) eltérése a CarpatClim adatbázistól (2010).

A nyári időszakban a felhőborítottság hatása is észrevehető: a BATS_UW szimuláció nagymértékü (2-3 ${ }^{\circ} \mathrm{C}$-os) alulbecslését a felhőzet felülbecslése okozhatja; a CLM_HO esetén 
viszont a felhőzet alulbecslése, így a hőmérsékleti értékek felülbecslése tapasztalható föleg az alföldi területeken (3. ábra).

A hőmérséklethez képest a csapadék esetén jóval kisebbek a különbségek a szimulációk között; télen a hegyvidéki területekre felülbecslés jellemző (4-5 mm/nap), míg nyáron inkább alulbecslés. Az alföldi területeken kisebbek a csapadékhibák, főleg a téli időszakban, amikor a csapadék mennyisége eleve kisebb. A CLM_HO szimuláció szárazabb a nyári időszakban (-2 mm/nap), illetve melegebb is a többi szimulációhoz képest. Ezek alapján a felszíni folyamatok kisebb mértékben befolyásolják a csapadékképző folyamatokat föleg a téli időszakban.

\section{Felhöboritottság}

A felhőborítottság esetén a szimulációk éves menete hasonló a referenciaadatokéhoz (szaggatott vonallal jelölt CarpatClim). A BATS_UW azonban jelentősen felülbecsülte az éves menetet (3. ábra), főleg a nyári időszakban, ami a nyári hőmérséklet alulbecslését okozhatja (2. ábra). Ezzel szemben a CLM_HO szimulációra inkább a felhőborítottság alulbecslése jellemző nyáron az alföldi területre. A CarpatClim maximuma a rendkívül csapadékos május borús időjárásával magyarázható a hegyvidéki területeken, amit a modellek jól visszaadtak. Ezzel ellentétben az Alföldön a téli hónapokra tehető a maximális felhőborítottság a hideg légpárnás helyzetek miatt (ami a gyakori inverziós helyzetek következménye), melyeket azonban a modellszimulációk kevésbé tudnak reprodukálni, így jellemzően alulbecslik ezeket az eseményeket (O’Brien et al., 2012). Holtslag et al. (2013) alapján a lokális lezárást alkalmazó PHR sémák alkalmazása javasolt stabilis rétegződés esetén (az UW séma is ezt a lezárást alkalmazza). Ezen kívül egy másodlagos maximum itt is megjelenik májusban, amelyet a BATS_UW szimuláció kivételével a szimulációk sikeresen visszaadtak.
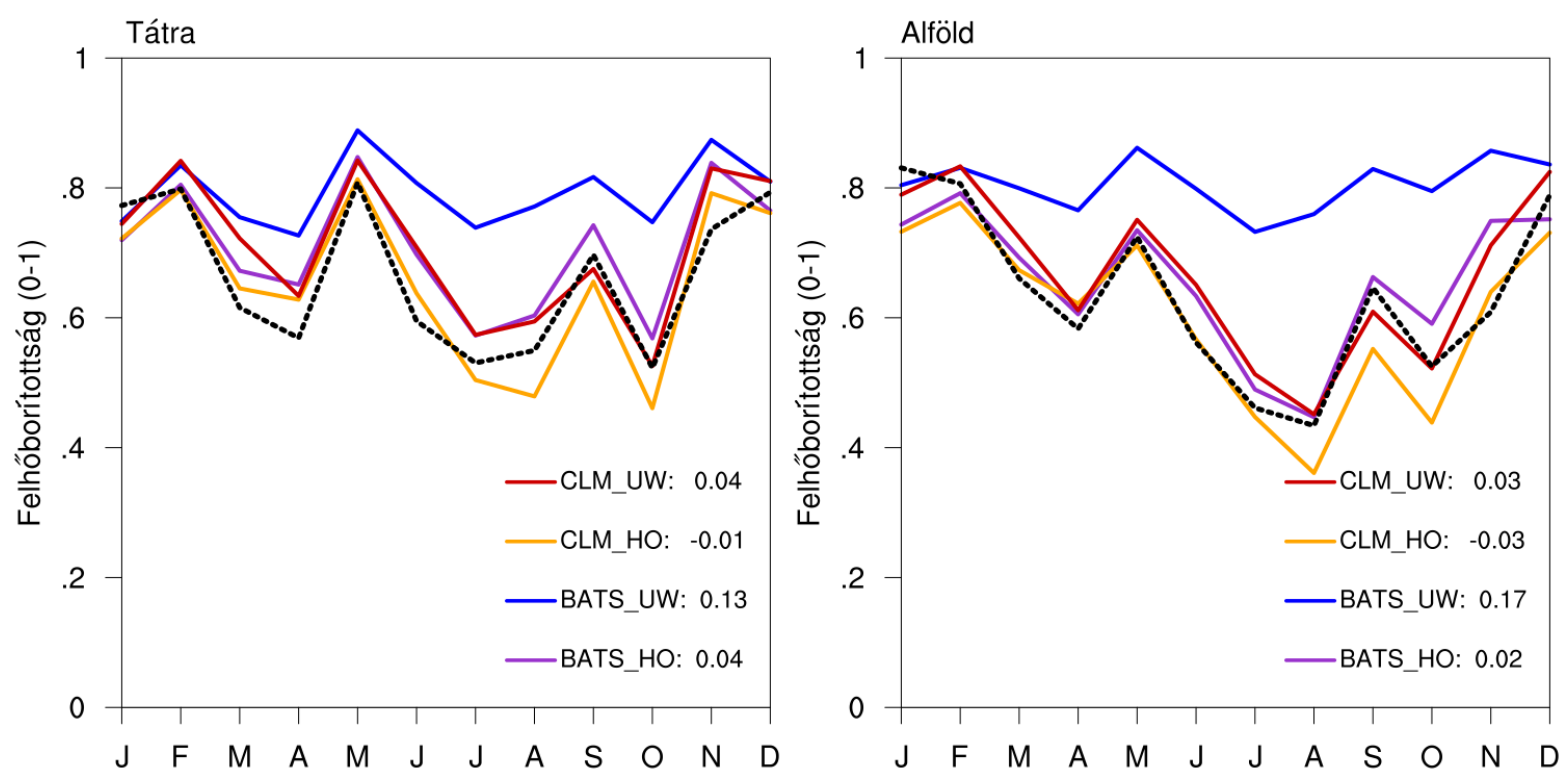

3. ábra: A havi átlagos felhőborítottság éven belüli eloszlása a Tátra térségére (jobb) és az Alföldre (bal). A fekete szaggatott vonal a CarpatClim referencia adatbázist jelöli, míg a jelmagyarázatban feltüntetett értékek a referenciától vett átlagos eltérést.

Megállapítható, hogy az UW séma jelentősen megnöveli a felhőborítottságot mind a két felszíni részmodell esetén - föleg a nyári hónapokban. Güttler et al. (2014) megállapítása alapján ezt az UW séma által generált magasabb vízgőz-tartalom okozhatja. A BATS és a CLM összehasonlítása alapján a BATS almodell alkalmazása mellett fordulnak elő magasabb felhő- 
borítottság értékek, melyből következnek a magasabb csapadékértékek is. Reboita et al. (2014) alapján a CLM almodell alkalmazása csökkenti az evapotranszspiráció mértékét, amely hatással van a felhő- és csapadékképződésre. Ez a RegCM 2010-re vonatkozó szimulációiban is megfigyelhető.

\section{Talajnedvesség}

A felszín-légkör rendszer kulcsfontosságú változója a talajnedvesség, amely nagymértékben szabályozza a szenzibilis és a látens hő közötti megoszlást (Seneviratne et al., 2010), illetve közvetlenül hat a planetáris határrétegre is. A 4. ábra a felsö $10 \mathrm{~cm}$-es réteg talajnedvességének éves menetét mutatja a két kiválasztott régióra. Jól látható, hogy míg télen a BATS felszíni modell tartalmaz jóval több talajnedvességet a hegyvidéki területen, addig a nyári hónapokban a CLM. A téli különbség összefüggésben állhat azzal, hogy a CLM esetén nagyobb a hóvastagság a BATS-hoz képest, így az ebben tárolt vízmennyiség még hó formában van jelen a felszínen, és éppen ezért nem tud beszivárogni a talajba. A planetáris határréteg séma hatása kevésbé befolyásolja a talajnedvesség értékeket, de összességében az UW sémával magasabb a talajnedvesség-tartalom mindkét terület esetén. A májusi többletcsapadék nem jelenik meg a talajnedvesség-tartalomban, mivel ez a mennyiség beszivárgott a mélyebb rétegekbe. Az alföldi területeken egyértelmüen a BATS szimulációk talajnedvesség-tartalma nagyobb egész évben; a szimulációk közötti legnagyobb különbségek a nyári hónapokra jellemzők: például a CLM_HO szimuláció esetén az augusztusi érték $15 \mathrm{~kg} / \mathrm{m}^{2}$-re tehető, míg a BATS_HO és BATS_UW esetén $25 \mathrm{~kg} / \mathrm{m}^{2}$ körüli ez az érték. Korábbi tanulmányok (Chung et al., 2018; Ajay et al., 2019) is alátámasztják a RegCM-re vonatkozó megfigyeléseinket: nevezetesen azt, hogy a CLM almodellt alkalmazó szimulációk kisebb talajnedvességet tartalmaznak. Az alacsony talajnedvesség mellett a hömérséklet felülbecslése és a csapadék alulbecslése (2. ábra) is megfigyelhető a CLM_HO esetén. Fontos azonban megjegyezni, hogy a talajnedvesség és a csapadék között kétféle visszacsatolási mechanizmus léphet fel. A pozitív visszacsatolás során a magasabb talajnedvesség következtében látenshö többlet alakul ki, ami nagyobb csapadékot eredményez és így a talajnedvesség egy pozitív visszacsatolást kap (Findell \& Eltahir, 2003). A negatív esetben pedig a fázisátalakulási hő visszafogja a csapadékképződést a hőmérséklet csökkenésén keresztül ezáltal kisebb lesz a talajnedvesség (Hohenegger et al., 2009).
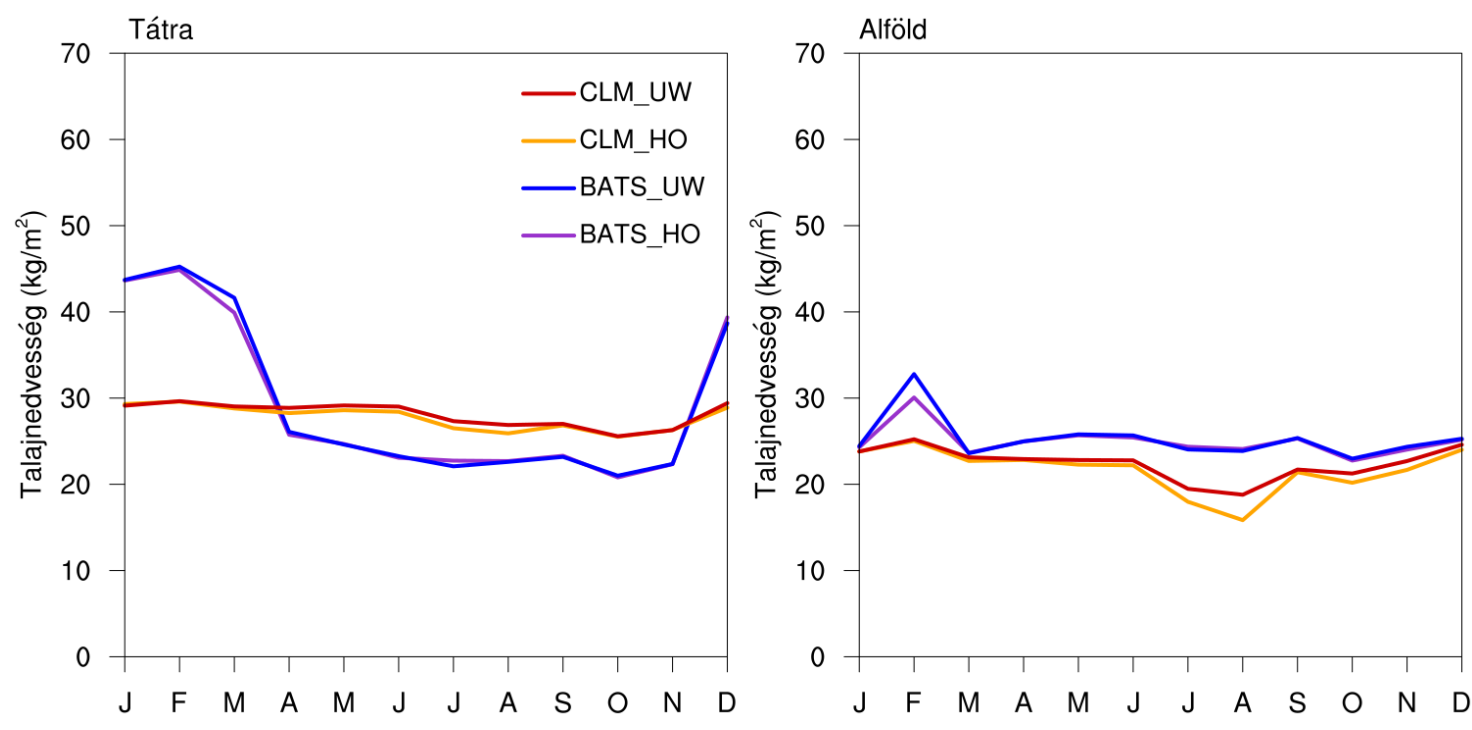

4. ábra: A havi átlagos talajnedvesség $\left(\mathrm{kg} / \mathrm{m}^{2}\right)$ éven belüli eloszlása a Tátra térségére (jobb) és az Alföldre (bal). 


\section{Felszini energiaegyenleg}

A földfelszín fontos tényező a légköri energia- és nedvességháztartási viszonyok kialakításában, így jelentős szerepet játszik az időjárási és éghajlati folyamatokban. A felszín és a légkör közötti energia-egyensúlyi mérleget a következő egyenlet írja le:

$$
N R+S H+L H+G+S M=0,
$$

ahol $N R$ a nettó sugárzás, $S H$ a szenzibilis hőáram, $L H$ a látens hőáram, $G$ a felszíni hőáram, míg $S M$ a hóolvadásból származó hőáram. A RegCM outputok csak az első három komponenst tartalmazzák, így a továbbiakban azok éves menetével foglalkozunk (5. ábra). 2010-ben a nettó sugárzás visszaesését a májusban megnövekedett csapadék okozta, míg a másodlagos minimum szeptemberre tehető. Az alföldi területen a maximum augusztusra esett. A látens hőáram a BATS esetén magasabb értéket adott, mint a CLM-es futások, ami az alföldihez képest nagyobb talajnedvesség-tartalomra vezethető vissza a hegyvidéki területeken. Definíció szerint a szenzibilis és a látens hőáram arányát fejezi ki a Bowen-arány. Nagyobb talajnedvesség esetén a látens hő aránya nagyobb, következésképp a levegő felmelegítésére fordítható szenzibilis hő aránya kisebb. A nedvesebb felszín felett tehát azonos mennyiségü rendelkezésre álló energia esetén a levegö kevésbé melegedhet fel (Pielke, 2001). Az 5. ábrán jól látható, hogy a CLM-et alkalmazó szimulációk esetén magasabb értékek fordultak elő a szenzibilis hőáramot, a nettó sugárzást és a Bowen-arányt tekintve egyaránt. A magasabb szenzibilis hőáram lokálisan magasabb felszíni hőmérsékleteket okoz, mely a 2. ábra hibatérképein tükröződik. Ezzel szemben a látens hőáram mértéke kisebb a CLM esetén, mint a BATS esetén - ez az alacsonyabb talajnedvességből következik. A nettó sugárzást tekintve a CLM_HO szimuláció esetén a legnagyobbak az értékek, ami a felhőborítottság alulbecslésére vezethető vissza (3. ábra). A bemutatott eredmények alapján tehát a PHR sémáknak összességében kisebb a hatásuk, mint a felszíni almodelleké, ugyanakkor megállapítható, hogy az UW sémát alkalmazó szimulációk esetén alacsonyabb értékeket kaptunk az energiaegyenleg egyes komponenseire.
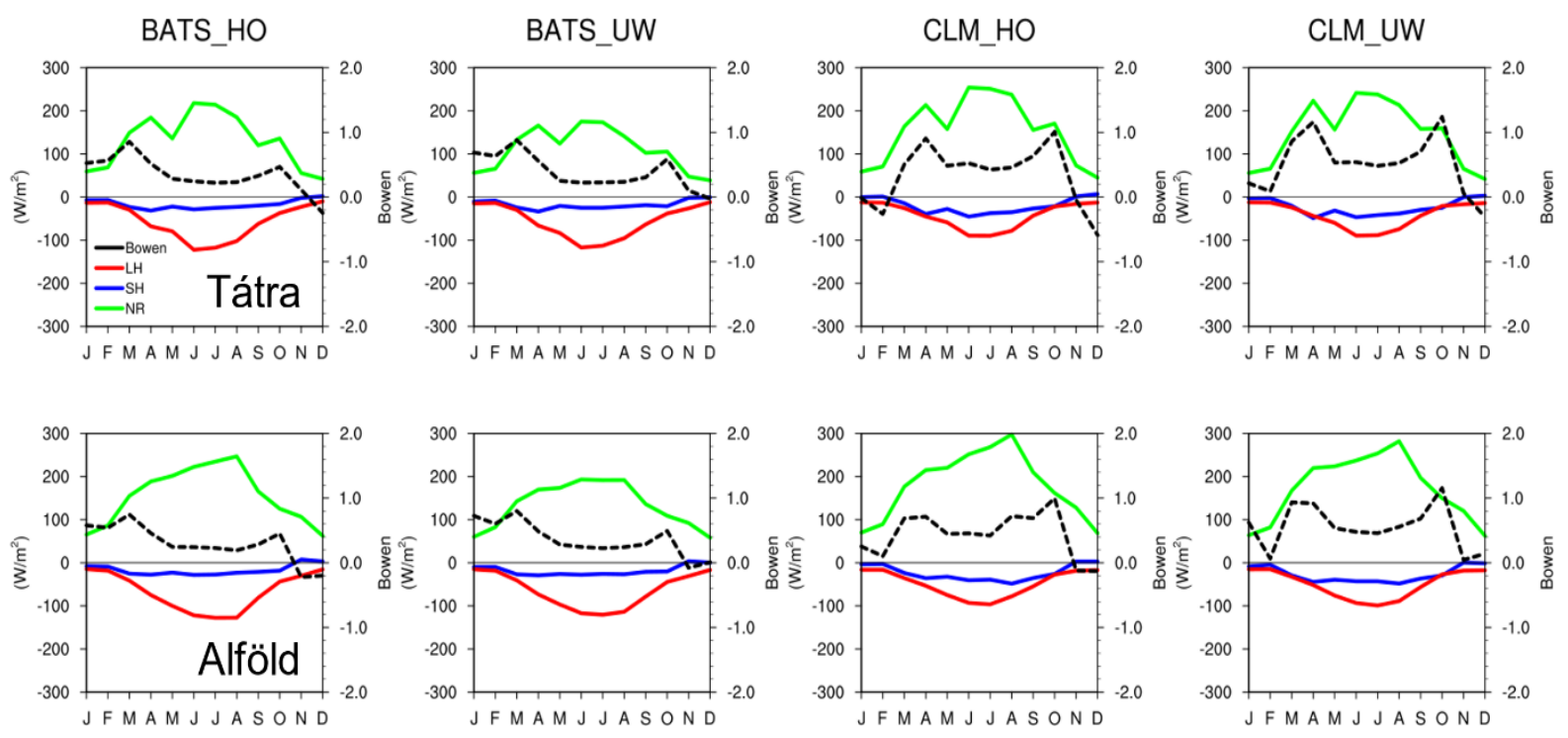

5. ábra: A havi átlagos nettó sugárzás (NR), szenzibilis ( $\mathrm{SH})$ és látens höáram $(\mathrm{LH})\left[\mathrm{W} / \mathrm{m}^{2}\right]$, illetve Bowen-arány éven belüli eloszlása a Tátra térségére (felső sor) és az Alföldre (alsó sor). A negatív értékek a szenzibilis és látens hőáram esetén az irányra utalnak. 


\section{Összefoglalás}

A doktori kutatás során a RegCM regionális éghajlati modellel végeztünk szimulációkat a Kárpát-medence térségére. Ebben a tanulmányban elsősorban a felszíni folyamatok parametrizációira koncentráltunk, s ennek érdekében két felszíni sémát (BATS és CLM4.5), illetve két planetáris határréteg sémát (Holtslag és UW) teszteltünk. Az eredmények alapján megállapítható, hogy a BATS_UW beállítással kapott nyári hőmérsékleti alulbecslést a nagyobb mennyiségü felhőzet és csapadék okozza, amely hatással van a beérkező rövidhullámú sugárzásra, így a nettó sugárzásra is. Ezen kívül a megnövekedett csapadék a talajnedvességre is hat, s ezáltal a szenzibilis és látens hőáram arányára, illetve a talajhőmérsékletre is. Megállapítható, hogy a felszíni almodell összességében nagyobb hatással van a csapadékra, a talajnedvességre, ennélfogva a szenzibilis és a látens hőáram mértékére is, mint a planetáris határréteget leíró parametrizáció választása. A vizsgálat során megállapítottuk, hogy a planetáris határréteg szerepe általában kisebb, mint a felszíni sémáé (kivétel a hőmérséklet esetén). Ugyanakkor az UW séma alkalmazása csökkenti a planetáris határréteg magasságát, növeli a felhőborítottságot, $\mathrm{s}$ ezáltal csökkenti a beérkező sugárzás mértékét és a felszínközeli hőmérsékletet is. Továbbá a talajnedvesség esetén kismértékü növekedés figyelhető meg a Holtslag sémához viszonyítva, ami hatással van a szenzibilis és látens höáram arányára. Összességében a szimulációk között viszonylag számottevőek a különbségek a sugárzási egyenleg tagjaira és a hőmérsékletre vonatkozóan, azonban a csapadék esetén nem.

A további kutatás során a felszíni sémák vizsgálatát kibővítjük a nagytérségü és a konvektív csapadéksémák tesztelésével, azaz a következő lépésben az tekintjük át, hogy a csapadéksémák megválasztása miként befolyásolja a szimuláció sikerességét. A tervezett átfogó elemzés segítséget nyújthat a legjobb sémakombináció kiválasztásában, valamint az egymással nem kompatibilis sémák kiszürésében. Végül a várható eredmények alapján dönthetünk a jövöre vonatkozó hosszabb távú éghajlati szimulációk készítéséhez alkalmazandó optimális modellbeállításokról.

\section{Köszönetnyilvánítás}

Kutatásainkat támogatta a Nemzeti Kutatási, Fejlesztési és Innovációs Alap K-129162 és K-120605 számú projektje, a Széchenyi 2020 program, Magyarország Kormánya és az Európai Regionális Fejlesztési Alap az AgroMo kutatási projekt (GINOP-2.3.2-15-2016-00028) keretében, valamint az Emberi Erőforrások Minisztériuma az ELTE Tématerületi Kiválósági Program 2020 - Intézményi Kiválósági Alprogram - (TKP2020-IKA-05) keretében. A CARPATCLIM Adatbázis előállítását az Európai Közösség támogatta a JRC intézeten keresztül kiírt kutatási program keretében.

\section{Hivatkozások}

Ajay, P., Pathak, B., Solmon, F., Bhuyan, P.K., Giorgi, F., 2019: Obtaining best parameterization scheme of RegCM 4.4 for aerosols and chemistry simulations over the CORDEX South Asia. Climate Dynamics, 53(1-2): 329-352. https://doi.org/10.1007/s00382-018-4587-3

Bretherton, C.S., McCaa, J.R., Grenier, H., 2004: A New Parameterization for Shallow Cumulus Convection and Its Application to Marine Subtropical Cloud-Topped Boundary Layers. Part I: Description and 1D Results. Monthly Weather Review, 132(4): 864-882. https://doi.org/10.1175/1520-0493(2004)132<0864:ANPFSC >2.0.CO;2

Chung, J. X., Juneng, L., Tangang, F., Jamaluddin, A.F., 2018: Performances of BATS and CLM land-surface schemes in RegCM4 in simulating precipitation over CORDEX Southeast Asia domain. International Journal of Climatology, 38(2): 794-810. https://doi.org/10.1002/joc.5211

Dee, D.P., Uppala, S.M., Simmons, A.J., Berrisford, P., Poli, P., Kobayashi, S., Andrae, U., Balmaseda, M.A., Balsamo, G., Bauer, D.P., Bechtold, P., 2011: The ERA-Interim reanalysis: 
Kalmár T., Pieczka I., Pongrácz R.: A RegCM4.7 regionális éghajlati modell érzékenysége a földfelszíni és a planetáris határréteg sémákra a Kárpát-medence térségében

Configuration and performance of the data assimilation system. Quarterly Journal of the Royal Meteorological Society, 137(656): 553-597. https://doi.org/10.1002/qj.828

Dickinson, R., Henderson-Sellers, A., Kennedy, P., 1993: Biosphere-atmosphere Transfer Scheme (BATS) Version 1e as Coupled to the NCAR Community Climate Model (p. 3040 KB).

UCAR/NCAR. https://doi.org/10.5065/d67w6959

Elguindi, N., Bi, X., Giorgi, F., Nagarajan, B., Pal, J., Solmon, F., Rauscher, S., Zakey, A., O'Brien, T., Nogherotto, R., Giuliani, G., 2014: Regional climatic model RegCM Reference Manual version 4.5. ITCP, Trieste, Italy. 37p.

Findell, K.L., Eltahir, E.A., 2003: Atmospheric controls on soil moisture-boundary layer interactions. Part I: Framework development. Journal of Hydrometeorology, 4(3): 552-569. https://doi.org/10.1175/1525-7541(2003)004<0552:ACOSML>2.0.CO;2

Güttler, I., Branković, Č., O'Brien, T. A., Coppola, E., Grisogono, B., Giorgi, F., 2014: Sensitivity of the regional climate model RegCM4.2 to planetary boundary layer parameterisation. Climate Dynamics, 43(7-8): 1753-1772. https://doi.org/10.1007/s00382-013-2003-6

Hohenegger, C., Brockhaus, P., Bretherton, C.S., Schär, C., 2009: The soil moisture-precipitation feedback in simulations with explicit and parameterized convection. Journal of Climate, 22(19): 5003-5020. https://doi.org/10.1175/2009JCLI2604.1

Holtslag, A.A.M., De Bruijn, E.I.F., Pan, H.L., 1990: A high resolution air mass transformation model for short-range weather forecasting. Monthly Weather Review, 118(8): 1561-1575. https://doi.org/10.1175/1520-0493(1990)118<1561:AHRAMT>2.0.CO;2

Holtslag, A.A.M., Svensson, G., Baas, P., Basu, S., Beare, B., Beljaars, A.C.M., Bosveld, F.C., Cuxart, J., Lindvall, J., Steeneveld, G.J., Tjernström, M., 2013: Stable atmospheric boundary layers and diurnal cycles: challenges for weather and climate models. Bulletin of the American Meteorological Society, 94(11): 1691-1706. https://doi.org/10.1175/BAMS-D-11-00187.1

Kalmár, T., Pieczka, I., Pongrácz, R., 2020: A sensitivity analysis of the different setups of the RegCM4. 5 model for the Carpathian Region. International Journal of Climatology. https://doi.org/10.1002/joc.6761

Knist, S., Goergen, K., Buonomo, E., Christensen, O.B., Colette, A., Cardoso, R.M., Fealy, R., Fernández, J., García-Díez, M., Jacob, D., Kartsios, S., 2017: Land-atmosphere coupling in EURO-CORDEX evaluation experiments. Journal of Geophysical Research: Atmospheres, 122(1): 79-103. https://doi.org/10.1002/2016JD025476

O'Brien, T. A., Chuang, P. Y., Sloan, L. C., Faloona, I. C., Rossiter, D. L., 2012: Coupling a new turbulence parametrization to RegCM adds realistic stratocumulus clouds. Geoscientific Model Development, 5(4): 989-1008. https://doi.org/10.5194/gmd-5-989-2012

Oleson, K.W., Lawrence, D.M., Gordon, B., Flanner, M.G., Kluzek, E., Peter, J., Levis, S., Swenson, S.C., Thornton, E., Feddema, J., Heald, C.L., 2010: Technical Description of Version 4.0 of the Community Land Model (CLM) (No. NCAR/TN-478+STR). Boulder, CO: University Corporation for Atmospheric Research, pp. 257. https://doi.org/10.5065/D6FB50WZ

Pieczka, I., Pongrácz, R., André, K.S., Kelemen, F.D., Bartholy, J., 2017: Sensitivity analysis of different parameterization schemes using RegCM4. 3 for the Carpathian region. Theoretical and Applied Climatology, 130(3-4): 1175-1188. https://doi.org/10.1007/s00704-016-1941-4

Pielke, R. A., 2001: Influence of the spatial distribution of vegetation and soils on the prediction of cumulus Convective rainfall, Rev. Geophys., 39(2), 151-177, https://doi.org/10.1029/1999RG000072

Reboita, M.S., Fernandez, J.P.R., Llopart, M.P., da Rocha, R.P., Pampuch, L.A., Cruz, F.T., 2014: Assessment of RegCM4. 3 over the CORDEX South America domain: sensitivity analysis for physical parameterization schemes. Climate Research, 60(3): 215-234. https://doi.org/10.3354/cr01239

Seneviratne, S.I., Corti, T., Davin, E.L., Hirschi, M., Jaeger, E.B., Lehner, I., Orlowsky, B., Teuling, A.J., 2010: Investigating soil moisture-climate interactions in a changing climate: A review. EarthScience Reviews, 99(3-4): 125-161. https://doi.org/10.1016/j.earscirev.2010.02.004

Szalai, S., Auer, I., Hiebl, J., Milkovich, J., Radim, T., Stepanek, P., Zahradnicek, P., Bihari, Z., Lakatos, M., Szentimrey, T., Limanowka, D., Kilar, P., Cheval, S., Deak, Gy., Mihic, D., Antolovic, I., Mihajlovic, V., Nejedlik, P., Stastny, P., Mikulova, K., Nabyvanets, I., Skyryk, O., Krakovskaya, 
Kalmár T., Pieczka I., Pongrácz R.: A RegCM4.7 regionális éghajlati modell érzékenysége a földfelszíni és a planetáris határréteg sémákra a Kárpát-medence térségében

S., Vogt, J., Antofie, T., Spinoni, J., 2013: Climate of the Greater Carpathian Region. Final Technical Report. www.carpatclim-eu.org

Tiedtke, M., 1989: A comprehensive mass flux scheme for cumulus parameterization in large-scale models. Monthly Weather Review, 117(8): 1779-1800. https://doi.org/10.1175/15200493(1989)117<1779:ACMFSF>2.0.CO;2

Torma, C., E. Coppola, F. Giorgi, J. Bartholy, R. Pongrácz, 2011: Validation of a High-Resolution Version of the Regional Climate Model RegCM3 over the Carpathian Basin. J. Hydrometeor., 12: 84-100. https://doi.org/10.1175/2010JHM1234.1

Varga, A.J., Breuer, H., 2020: Sensitivity of simulated temperature, precipitation, and global radiation to different WRF configurations over the Carpathian Basin for regional climate applications.

Climate Dynamics, 55: 2849-2866. https://doi.org/10.1007/s00382-020-05416-x

\section{ORCID}

Kalmár T. (D) https://orcid.org/0000-0003-0405-4404

Pieczka I. (D) https://orcid.org/0000-0001-5657-9494

Pongrácz R. (iD https://orcid.org/0000-0001-7591-7989 